\title{
Povsem nenavadno stoletje: humanizem v Istri i6. stoletja med panegirikom in preklicem spomina
}

\author{
Gregor Pobežin \\ UP FHŠ, Oddelek za arheologijo in dediščino \\ ZRC SAZU, Inštitut za kulturno zgodovino \\ gregor.pobezin@fhs.upr.si
}

\section{Uvod}

Prispevek se osredotoča na znanstvo, morda celo (prijateljski?) odnos med dvema humanistoma, ki sta pomembno zaznamovala intelektualno krajino severne Istre oz., natančneje, Kopra v 16. stoletju, namreč Andrea Diva in Petra Pavla Vergerija. Koprski prevajalec in pesnik Andreas Divus je svojemu someščanu, škofu Petru Pavlu Vergeriju, posvetil predgovor k svojemu monumentalnemu prevodu Iliade, v katerem je vsebinsko preoblikoval moralne prologe antičnega zgodovinopisca Salustija iz prvega stoletja pr. Kr. Izbira tematike morda ni zgolj humanistični literarni topos in sredstvo dobrikanja vplivnemu someščanu; že površno branje razodene, da se je Divus v svojih posvetilih tesno naslonil na znani antični vir, pri čemer je njegova raba antičnih abstraktnih konceptov globlja in bolj domišljena, kakor se zdi na prvi pogled. Filološka primerjava citiranih besedil pokaže, da je Divus - podobno kakor številni drugi humanisti njegovega časa - z literarnim prekvašenjem antičnih besedil (v našem primeru Salustija) hote dosegel vsebinski učinek, ki sega onkraj golega poklona dobrotniku (in mecenu?). Obenem pa dva panegirična uvoda k Divovim pesnitvam zaznamujeta tudi pričetek Vergerijeve »koprske epizode«, ki se je le desetletje kasneje končala $\mathrm{z}$ njegovim izgonom in izobčenjem. 


\section{Umbilicus mundi Homericus}

Leta 1537 je Koper (Justinopolis) na neki način postal središče sveta. Tega leta je namreč Andreas Divus izdal prevod Iliade in Odiseje, prvi integralen prevod teh dveh Homerjevih pesnitev »na latinskem zahodu«. O Divu vemo zelo malo, skoraj ne več kakor tisto, kar sam pove o sebi v spremnih besedilih k svojim prevodom, vsekakor pa ne dovolj, da njegovo ime ne bi sprožalo (neprimerno) aktualiziranih ugibanj o njegovem izvoru (Benedetto 2005; Gantar 1970), ki pa ne presenečajo: vprašanja, kako se je v resnici pisal Divus, niso nič novega (Teza 1903). Vprašanje Divove istovetnosti zaenkrat torej ostaja neznanka (morda je tako tudi bolje), čeprav je o rodbini Divo v Justinopolisu sicer mogoče nanizati kar nekaj podatkov (Pobežin 2016, 86-88).

Divov prevod ni mojstrovina (Marinčič 2016, 34), deležen je bil hudo neprizanesljivih kasnejših ocen (Gantar 1970, 273-74), a je bil kljub kritikam deležen tudi številnih ponatisov. A tudi če se je mogoče vdati stališču, da Divus ni kaj prida pesnik ali prevajalec (ta trditev pa bi bila vsekakor krivična - Marinčič 2016, 34-37), pa se je v odnosu do svojega vrstnika po kraju rojstva (in letih?) razkril kot izviren mislec in morda tudi ostroumen opazovalec.

Svoj prevod je Divus v prologih, sestavljenih v pisemski obliki, posvetil padovanskemu škofu Aloisiu Pianiju ter Koprčanoma Petru Pavlu Vergeriju in Otonellu Vidi. V pismih svojima vrstnikoma Divus o sebi pove kaj malo (omeni, denimo, da je med prevajanjem Homerja porabil veliko družinskega denarja - magna rei familiaris iactura), precej več pa prologi povedo o njegovi namerni izbiri literarnega toposa, pri kateri se je tesno naslonil na antičnega zgodovinarja Salustija. V prologu, namenjenemu Vergeriju, Divus piše:

Tebe, preslavni Vergerij, čigar značaj in učenost sem vedno občudoval čez vse, sem izbral kot edinega od vseh in tvojemu imenu želim posvetiti te sadove svojega duha. Tega nisem storil zato, ker bi bil mislil, da lahko ti s posvetitvijo mojih spisov še bolj zasloviš (saj si že tako poln vse hvale, da tvojemu slovesu ni mogoče ničesar več dodati), temveč da bi čez mene in čez moje spomenike, ki bi sami po sebi morda ostali precej $v$ temi, $z$ napisom tvojega imena razlil nekakšno luč in svetlobo.

Kje je človek, ki bi se mogel s tabo upravičeno primerjati v vsakršni slavi? V Benetkah si živel tako, da so te vsi ljubili, večina pa tudi čas- 
tila in spoštovala. Vendar si se, podžgan od želje po večji slavi, hotel preseliti $v$ Rim, kjer bi bili darovi tvoje nadarjenosti, da se tako izrazim, vidni v bolj obiskanem gledališču. In ko si prišel v Rim, si že čez nekaj dni postal tako zaupen prijatelj papežu Klementu VII. in si si pridobil naklonjenost tega tako velikega in dobrohotnega moža, da ti je sam od sebe zaupal ugledno poslanstvo $k$ nepremagljivemu kralju Ferdinandu, kar je poprej odrekel mnogim, ki so se za to potegovali. Kaj naj rečem, kako je v tej dolžnosti vzblestela luč tvoje razumnosti in preudarnosti? Bog mi je priča, v tistem delu sveta ni človeka, ki te ne bi z najvišjimi in s popolnoma iskrenimi hvalnicami povzdigoval do neba in te skrbno in sveto ohranil v svojem spominu. Ko pa je papež Klement umrl, si na pismeni poziv papeža Pavla III. prihitel v Rim. Tam si mu v razumnih besedah dal poročilo o uspehih svojega poslanstva, tako da mu niti na misel ni prišlo, da bi na tvoje mesto postavil koga drugega, ampak te je odposlal š̌e večjimi in obsežnejšimi pooblastili. Ko je namreč sklenil sklicati koncil, da bi odpravil zmote, je želel, da se stabo sestanejo knezi iz vse Nemčije, da bi ti skrbno preiskal njihovo razpoloženje in ugotovil, kaj sodijo o koncilski konstituciji. Ko si to zadevo naglo in z največjim priznanjem opravil, si se vrnil v Rim, od tam si se napotil v Neapelj spet kot papežev odposlanec $k$ cesarju. Naposled si se okrašen s škofovsko častjo svoje domovine vrnil domov, kjer uživaš v spoštljivem zatišju in kjer si najrajši odpočiješ $v$ študiju svete književnosti, ki si jo vedno goreče ljubil. V tem očitno posnemaš svoje prednike, predvsem učenega moža, velikega govornika Petra Pavla Vergerija, po katerem si prevzel ime in krepost. Ta mož je bil najslavnejša zvezda svojega časa, vse kaj drugega kot poprečen okrasek; zablestel je na koncilu $v$ Konstanci, ki je bil pred sto leti, bil je dober strokovnjak $v$ vseh svobodnih znanostih, o čemer pričajo njegovi spisi, ki jih je mnogo objavil. Bil je zelo priljubljen pri škofih svojega časa, prav tako pa pri cesarju Sigismundu, pri katerem je tudi umrl, kot berem v poročilih učenjakov. Vse to so $v$ resnici velike in neminlive stvari: toda ti si s svojo edinstveno krepostjo storil in dosegel ne samo to, da ne potrebuješ nobenega priporočila svojih prednikov, temveč da so celo oni zaradi odličnih lepot tvojega značaja in tvoje učenosti danes pri nas še slavnejši.

Ker vem, kako iz srca so ti naklonjeni vsi, ki te poznajo (saj ni skoraj nikogar, ki te ne bi hotel - očaran od tolike hvale - spremljati 
$z$ največjo blagohotnostjo in spoštovanjem), sem upal, da bom žes samim tem posvetilom svojih del lahko navezal nase ne toliko tebe, saj se že dolgo štejem med tvoje zaupne prijatelje, temveč vse svoje someščane, ki si jim ti tako zelo pri srcu. O koristnosti svojega dela in o avtorjevem priporočanju ne bom ničesar govoril, da ne bi, kot se temu reče, ob sončni svetlobi prižigal svetilke. Naj torej končam, š prej pa te prosim, bodi prepričan, da ti ostajam in da sem ti vedno ostal iskreno vdan! Pozdravljen, čast in okras svoje domovine! (Gantar 1970, 275-76)

Panegirično pismo je obloženo z natančnimi podatki o Vergerijevi karieri. Vzpostavlja tudi (slabo izpričano) družinsko sorodstvo s Petrom Pavlom Vergerijem starejšim; med njima vleče jasne vzporednice (ne pozabi omeniti vloge Vergerija st. pri koncilu v Konstanci), ki se dozdevno ponujajo na dlani, čeprav med njima obstajajo tudi povsem subtilne povezave (Marinčič 2018). Niti kronološko ni povsem nemogoča misel, da je Vergerij Divu (kot svojemu varovancu? - Marinčič 2016, 41) kar sam namignil, kaj naj vsebuje predgovor $\mathrm{k}$ očitno pomembnemu prevodu (Pobežin 2018b, 102), kajti predgovor na tistem mestu, kjer omenja Vergerijevo vrnitev domov - da se je namreč »okrašen s škofovsko častjo svoje domovine vrnil domov, kjer uživa v spoštljivem zatišju in kjer si najrajši odpočije v študiju svete književnosti« -, opušča pomemben del Vergerijeve osebne kronologije. Vergerij namreč po koncu svojih diplomatskih misij (decembra 1535) ni bil nagrajen $z$ novo nunciaturo, a je po korespondencah sodeč pri papežu še užival dovolj zaupanja (Schutte 1977, 15), da ga je »nagradil« Z odročno škofijo v Modrušu. Za Vergerija je bilo to imenovanje nazadovanje, zato bržkone ni presenetljivo, da podatek o njegovi kratkotrajni nastavitvi v nepomembni škofiji pri Divu manjka, omenjena pa je šele nastavitev v Kopru ob koncu leta 1536, ko je nadomestil pokojnega koprskega škofa Valvassorija. Tudi to imenovanje je bilo sicer za Vergerija diplomatski in gmotni poraz: bil je odrezan od nadaljnjih koncilskih priprav, obenem pa je bil pahnjen v finančno stisko. Obubožana koprska škofija je omogočala precej skromno letno rento, katere del je moral izplačevati Antoniu Eliu (?-1576), čemur se je uprl s civilno tožbo. Pri Eliu, ki je užival podporo družine Farnesejev, si je s tem nakopal zamero, o kateri bomo še spregovorili v nadaljevanju. Zaradi tega in pa zaradi pragmatičnega stališča, ki ga je zavzel po opravljeni diplomatski misiji v nemških deželah, da je papeško vztrajanje pri sklicu pomiritvenega koncila na papeških tleh nerealno, je Vergerij na koncilu, ki je z zasedanjem pričel leta 1537 (prvi sklic je bil v Vicenzi), postal per- 
sona non grata. Morda je prav zaradi tega pomen koncila v Divovem pismu zožen na skromno omembo »koncila, namenjenega odpravi zmot«, ki ga je Vergerij opravil »naglo in z največjim priznanjem«, kar drži le deloma: Vergeriju nemških knezov ni uspelo prepričati, naj popustijo pri temeljni zahtevi, da se mora koncil zgoditi na nemških tleh. Kljub temu, da je bil to neuspeh, Divov prolog tu zavzame tako rekoč nasprotno stališče, in sicer da je Vergerijevo imenovanje za koprskega škofa njegov umik v otium: Koper - Justinopolis tu postane del literarnega toposa: postane Vergerijev Tusculum, kamor se je Vergerij v patricijski maniri vrnil k počitku »v študiju svete književnosti«. Toda obenem je misel, da Vergerij zdaj »uživa v spoštljivem zatišju ... kjer si najrajši odpočije v študiju svete književnosti, ki jo [je] vedno goreče ljubil«, preroški terminus ante quem: goreča ljubezen do evangelija je postala tudi eden od razlogov Vergerijeve pogube.

\section{Antična literarna predloga}

Tu pa se črpanje literarnih zgledov ne ustavi. Poleg toposa o otiumu se Divov prolog nasloni na tudi dosti bolj poglobljeno literarno tradicijo. V prologu, naslovljenem na Otonella Vido, Vergerijevega tajnika v Kopru, Divus pove:

$V$ preteklih letih sem dostikrat premišljeval, plemeniti Otonello, kako kratko in krhko je to naše življenje; zato sem pri sebi temeljito razmislil, kako neki bi dosegel to, da bi ne ustvaril vtisa, da sem življenje preživel molčé - in da bi pustil nase trajen spomin. Sprva kar nisem vedel, kako bi se tega lotil, kajti ponuja se mi kar nekaj različnih vrst udejstvovanja. Nazadnje sem svoja razmišljanja povzel takole: človek lahko na dva načina pride do slave, in sicer s telesnimi napori ali umskimi dosežki. Prvo si delimo z zvermi, drugo pa s samimi bogovi - to vem vse predobro; pri moji veri, rekel bi, da bi bil še bolj nespameten kot Koreb, če bi se skušal do vsaj neznatne slave dokopati s telesno močjo namesto $z$ duševnimi zmožnostmi! [...] Je namreč morda še kaj slavnejšega, kot so Ahilova dejanja in njegova moč (da o ostalih sploh ne govorim)? In vendar bi bilo, kakor pravi tudi sam Ciceron, $v$ isti gomili, kjer počiva njegovo telo, pokopano tudi njegovo ime, če ga ne bi v spominu ovekovečil največji vseh pesnikov. Seveda dobro vem, da so si poleg onih, ki so kaj dosegli z dejanji, nemalo hvale prislužili tudi tisti, ki so dejanja drugih opisali, in ker vem tudi, da so bili malodane enake slave kot najimenitnejši pisci deležni tudi odlični prevajalci, sem sklenil 
posnemati zgled številnih nadvse učenih mož - pač v pričakovanju, da bom opravil veliko in marsikomu koristno delo, če nekatere grške pesnike prevedem v latinski jezik. (prev. G. Pobežin)

$\mathrm{V}$ prologu, namenjenem Vergeriju, beremo še naslednjo misel:

Za lépo in za hvalo imamo na voljo naravnost imenitne instrumente, namreč dušo in pamet - in vendar ju zlorabljamo v nizkotne namene: raje kot da bi ubogali razum, sledimo pohlepu; v ničvredne reči smo prepričani, kakor da so hvalevredne - in to, kar je hvalevredno, imamo za ničvredno. Stari pa - bodisi filozofi bodisi ravnatelji mest - še kar živé v slavi, dasiravno so že davno umrli; večnega priznanja nikoli ne bi dosegli, če vseh svojih zamisli in dejanj ne bi usmerjali zgolj $v$ krepost $v$ prepričanju, da si morajo po svojih močeh za krepost prizadevati predvsem zavoljo sebe. V to tudi sam že od mladih nog trdno verjamem, čeprav me nihče ni tega učil - le narava mi je vcepila to prepričanje. (prev. G. Pobežin)

V obeh prologih se Divus močno nasloni na antičnega zgodovinopisca Salustija, ki je za dve svoji temeljni monografiji - Katilinovo zaroto in Jugurtinsko vojno - pripravil obsežen moralno-filozofski prolog. Obe besedili sta bili, kakor bomo pokazali v nadaljevanju, obvezno čtivo tako v srednjem veku kakor v renesansi, a sta bili deležni zanimivih, vsakokrat pa priložnostnih (pre)branj.

Divus v svojih prologih zavzame moralistično držo, ki jo lahko dobro razumemo le, če razvezano citiramo tudi ustrezne Salustijeve pasuse. V (starejši) Katilinovi zaroti Salustij v uvodu začne:

Vsi ljudje, ki se trudijo povzpeti se nad ostala bitja, bi si morali na vso moč prizadevati, da ne bi življenja premerili molče kakor ovce, $k i$ jih je narava ustvarila sklonjene $k$ tlom in pokorne zgolj svojemu trebuhu. Vsa naša ustvarjalna moč je v telesu in duhu. Duha imamo, da ukazuje, telo pa, da sledi; v prvem smo podobni bogovom, drugo nam je skupno zživalmi. Zato se mi zdi pravilneje, da si za slavo prizadevamo $z$ duhovnimi in ne toliko s telesnimi sposobnostmi; in ker je življenje, ki nam je dano, kratko, moramo doseči, da bo spomin na nas kar se da dolgotrajen. Slava bogastva in lepote je namreč nestanovitna in krhka, slava kreposti pa sijoča in večna. [...] Lepo je z dejanji koristiti državi, a tudi govoriti v njeno korist ni brez vsakega smisla. Človek se lahko proslavi bodisi v 
miru bodisi v vojni; velikih časti so deležni tako tisti, ki so dejanja storili, kot tudi tisti, ki so drugih dejanja opisali. Meni pa se le zdi, da je, čeprav je pisec zgodovine deležen skromnejše slave kot tisti, $k i$ jo ustvarja, zgodovino pisati nadvse težko; najprej zato, ker je treba $v$ besedah enakovredno prikazati dejanja, zatem zato, ker ima večina grajanje prekrškov za besede zlobe in nevoščljivosti. Kadar pa omenjaš izjemno krepost in slavo izvrstnih posameznikov, nekaj kar se vsakomur zdi lahko dosegljivo, to naleti na ravnodušen odziv, kaj več pa celo obvelja za izmišljeno laž.

Prolog k Jugurtinski vojni:

Po krivem se človeštvo pritožuje zastran svoje narave, češ da ji, šibki in obsojeni na kratek vek, vladajo prej naključja kakor pa kreposti. Po tehtnem premisleku namreč ugotoviš prav nasprotno: da ni večje in imenitnejše stvari in da človeški naravi bolj kakor zmožnosti ali časa primanjkuje marljivosti. ${ }^{2}$

Oba Divova prologa v obliki pisem tematizirata "salustijanske« topose (za natančno primerjavo besedil gl. Pobežin 2016, 90-92). Na tem mestu bi lahko Divu celo očitali, da je povsem neizviren: če se »ni izkazal kot prevajalec«, se ni izkazal niti kot izviren apologet svojih prevodnih strategij. Salustij je bil pogosto branje (Osmond 1995).

Vendar pa naslanjanje na izbrano literarno predlogo seže globlje. Salustij je namreč v obeh svojih prologih redefiniral enega najtemeljnejših pojmov rimskega republikanskega idearija - krepost - in tako bralcu omogočil novo razumevanje tega kardinalnega pojma. Salustijeva redefincija kreposti (lat. virtus) ruši dotedanje (idealno) razumevanje, ki je sicer krepost raztegovalo tudi onkraj modernega koncepta morale, poleg tega pa so že $\mathrm{v}$ pozni republikanski dobi njeno definicijo načenjale različne interpretacije (McDonnell 2006, 271-90).

Dilema, ki jo Salustij razrešuje, je razcep med na videz jasnima antitetičnima paroma »molk - spomin« (memoria - silentium), »telo - razum« (corpus - ingenium), in se sprašuje, ali je res mogoče doseči slavo in trajen spomin (gloria in memoria) zgolj na polju posameznikovega javnega udejstvovanja (imperium), torej $\mathrm{v}$ vojni ali v politiki. Poudarjeno moralistični Salustijevi (in Divovi) besedili izpostavljata krepost (virtus) v odvisnosti od človeške narave (natura). Pri tem moramo posebej izpostaviti globoko do-

\footnotetext{
Sall. C. 1.1-1.4. Prevedel G. Pobežin.
}

Sall. Iug. 1.1-2. Prevedel G. Pobežin. 
mišljeno dimenzijo uporabljenega izraza silentium, ki se ponavlja tudi pri Divu. Smisel Salustijevega prologa lahko na kratko povzamemo takole: človek (omnes homines), ki ga od ostalih živih bitij (ceteris animalibus) ločuje predvsem prizadevanje, da bi jih presegel, preseči pa jih more le z izbiro pravilnega načina delovanja, kajti v telesni moči jih preseči ne more - ta mu je namreč $\mathrm{z}$ drugimi bitji skupna in ga $\mathrm{v}$ tem pogledu priklepa $\mathrm{v}$ njihov svet. Da bi potemtakem dosegel ta ideal - da torej življenja ne bi premeril molčé (ne vitam silentio transeant), mora izbrati tisto, kar mu je skupno z bogovi (cum deis commune est), to pa je dar razmišljanja in govora. Silentium - molk - predstavlja pasivno nasprotje izrazov gloria in memoria in je potemtakem samoumevna polovica zgoraj omenjenega antitetičnega para. Izraz ne vitam silentio transeant v prologu »Katilinove zarote" ima pomembno družbeno dimenzijo - razumeti ga moramo predvsem v smislu javnega življenja, v katerem je človek - njegova funkcija. Kakor bomo videli, je to tista stična točka, ki Diva in Salustija bistveno povezuje, toda k temu se še vrnemo.

Tudi kot advokat lastne (spodletele) politične kariere torej Salustij te dihotomne opozicije načenja tako, da idejno polje kreposti razširi tudi na pisanje: »lepo je $\mathrm{z}$ dejanji koristiti državi, a tudi govoriti v njeno korist ni brez vsakega smisla " (pulchrum est bene facere rei publicae, etiam bene dicere haud absurdum est), če gre seveda za pisanje, ki je - tako kakor dejanja (bene facere) v politični ali vojni palestri - v korist države. V rimski tradiciji je (javni) govor nekaj državotvornega, čemur že v tretjem stoletju pr. Kr. dodajo historiografsko dimenzijo rimski protozgodovinarji (analisti), torej se lahko v korist države udejstvujejo tudi zgodovinarji. Toda zgodovinopisje je bilo $\mathrm{v}$ republikanskem Rimu literarni žanr upokojenih senatorjev: to je bonum otium (C. 4.1) - plemenito brezdelje (upokojitev), ki šele sledi resničnemu vencu slave in spomina vrednih dejanj (gloria, memoria): zgled je že oče rimskega zgodovinopisja Kvint Fabij Piktor. Tu ni veliko manevrskega prostora: vsak Rimljan je vedel, kakšen cursus honorum tlakuje pot k slavi in spominu; šele homines novi prvega stoletja pr. Kr. so uspeli do temeljev stresti to tradicijo, ko jih nihče več ni mogel ustaviti. Prav tu Salustij ponudi (samo)odrešujoči izhod (C. 3,2): »Meni pa se le zdi, da je, čeprav je pisec zgodovine deležen skromnejše slave kot tisti, ki jo ustvarja, zgodovino pisati nadvse težko; najprej zato, ker je treba z besedami ustrezno prikazati dejanja, zatem zato, ker ima večina grajanje prekrškov za besede zlobe in nevoščljivosti.« Stališče, da je zgodovino tem težje pisati, ker je treba "v besedah treba enakovredno prikazati dejanja (facta dictis exaequ- 
anda sunt), deluje naivno šele danes - in vsekakor nič bolj kakor trditev, da je treba zgodovino pisati wie es eigentlich gewesen ist. Vsekakor pa Salustij, ki je imel za takšno izjavo podlago v literarni tradiciji (Izokrat, Panegirik 4, 13), ni bil dovolj naiven, da bi mislil, da so njegova besedila veren posnetek neke pretekle resničnosti; argument pač jasno kaže na to, da je zgodovina vredna slave.

Salustijeva antiteza je potemtakem jasna: kljub temu, da zgodovinopisca ne obsije enaka slava kakor njegov predmet opisovanja (haudquaquam par gloria sequitur scriptorem et actorem rerum), je pisanje zgodovine težko (tamen in primis arduom videtur res gestas scribere), zato slava pripada tudi zgodovinarju. Divus v svojih pisemskih predgovorih Otonellu Vidi in Vergeriju potemtakem zavzame veliko samoumevnejšo držo, kakor se zdi na prvi pogled, Salustijeva misel, da je »lepo z dejanji koristiti državi, a tudi govoriti v njeno korist ni brez vsakega smisla « (pulchrum est bene facere rei publicae, etiam bene dicere haud absurdum est), pa je zgolj dobra iztočnica. Dejstvo, da Divus v tem pogledu ni izviren, mu sploh ne škodi, kajti "pre-branja« antičnih besedil so bila med humanisti usus. Nekaj mu govori celo v prid: ker ne gre za pravnika ali »vsaj« zgodovinarja, ki bi imel »težko mirnodobno nalogo pisanja zgodovine«, pač pa »le« prevaja, je Divus Salustijevo dihotomno definicijo koristi za državo bene facere - bene dicere razširil še z bonum interpretem esse - da je kdo dober prevajalec. Divus se nam tu razkrije v vsej svoji ambicioznosti, ob kateri misel, da se bo skušal s svojim delom dokopati »vsaj do neznatne slave« (gloriolam mihi aliquam comparare), deluje ironično, če že ne lažno skromno.

Tu si moramo dovoliti še navedbo daljšega odlomka, ki nam bo pomagal $\mathrm{z}$ večjo gotovostjo otipati argument, s katerim je Salustij podprl svoje sporočilo, ki je v očeh povprečnega Rimljana lahko delovalo celo komično. $V$ ta namen je namreč moral redefinirati, kaj vse sodi v polje kreposti:

Vse, česar se ljudje oprimejo - oranje, plovba ali gradnja -, je odvisno od kreposti. Toda mnogi, ki jim je mar le za jed in spanec, neuki in brez omike, tavajo skozi življenje kakor brez vsakega cilja; tem telo proti naravi služi zgolj za užitke, duh pa jim je v breme. Njih življenje se mi zdi malodane smrt, ker je zavito v molk. Zdi se mi, da prav zares živi le tisti, ki si, osredotočen na neko opravilo, prizadeva za slavo, ki jo prinesejo izredna dejanja ali lepe čednosti. ${ }^{3}$ 
Navajanje vsakdanjih dejavnosti (arare, navigare, aedificare), ki bi v antiki prej sodile pod okrilje bukoličnega pesništva, služi kot podpora trditvi, da si človek lahko slavo prisluži tudi s pisateljevanjem (ali prevajanjem) - ki tako po Divovih besedah dobi »domovinsko pravico na zvezdnatem nebu «.

Salustijeva (pre)obsežna traktata, ki sta prešita s toposom o kreposti (virtus), predstavljata subtilen naratološki prijem: gre za komaj zaznaven pritisk na bralca pozne republikanske dobe. A tekst je s svojimi navideznimi moralnimi dilemami vabil k vedno novim, aktualiziranim branjem. Divus je v svojih panegiričnih pisemskih prologih to dilemo potreboval zgolj kot vsakokrat prikladno literarno ozadje - naslovnika takšnih podukov v resnici nista potrebovala. Toda onkraj Divove samopromocije in posrečene primerjave Vergerijevega otiuma s Salustijevim - oba sta bila na neki način marginalizirana lika - se podobnosti z antičnimi predlogami tu pravzaprav šele dobro začnejo. $Z$ uporabo Salustijeve literarne predloge je dosežen ravno nasprotni učinek od tistega, ki ga je Divus morda imel v mislih, če je res želel namigniti, da so se za Vergerija z umikom v Koper (v otium) končale dileme, hujše od prepada med latinskim in grškim jezikom (Marinčič 2016, 42), a to je zares jasno šele ob privilegiranih kasnejših branjih. Divov literarni manever se je potemtakem posrečil bolj, kakor je avtor morda sam pričakoval. Fabula docet: Vergerijevo življenje se je obrnilo tako, da so moralna pre-branja obeh prologov tako rekoč opis dilem, s katerimi se je soočil v dogodkih, o katerih Divus ni mogel še ničesar slutiti.

Od konca leta 1535, ko je dobil navodilo, naj se s svoje misije pri Schmalkaldenski zvezi vrne v Rim, do imenovanja za koprskega škofa se je Vergeriju zgodilo marsikaj. V tolažbo, ker so spodletela njegova diplomatska prizadevanja za sklic koncila na nevtralnem kraju (novico je dobil na poti v Neapelj, ki jo omenja tudi Divus), je bil imenovan v komisijo za prenovo, ki jo je vodil Gasparo Contarini (prav tu se je najbrž spogledoval z evangelizmom in s t. i. spirituali); Vergerij je z njim sodeloval vse do zbora v Regensburgu 1541. Ne neki način je Vergerij vsaj prek te komisije ostal razmeroma vpliven; kljub temu, da je bil »umaknjen« v modruško škofijo, je papež vsaj sklical koncil - in Vergerij je imel kot škof pravico do udeležbe na koncilu, tokrat ne kot diplomat, ampak kot cerkveni dostojanstvenik in ideolog. Vse od svojega imenovanja do leta 1541 je bil v Kopru le malo prisoten, delno zaradi že omenjenih težav z Eliem in s Farneseji, delno zaradi službe v Contarinijevi komisiji. A resne težave so se za Vergerija začele leta 1543 , ko je nanj prvič padel sum odpadništva; obtožbe je pomagal širiti 
prav Antonio Elio, zaradi vneme »v študiju svete književnosti, ki jo je vedno goreče ljubil«, kakor se izrazi Divus, pa se je zameril tudi lokalni duhovščini in faranom, ki jih je želel odvrniti od pretiranega čaščenja svetnikov (Schutte 1977, 174; Jambrek 1999). Inkvizicijski postopek proti Vergeriju se je vlekel od leta 1543 do 1549, ko je naposled obupal in zapustil Italijo. V odsotnosti je bil obsojen herezije in izobčen, na neki način že drugič: prvič je bil izobčen kot nuncij, drugič kot škof.

Vztrajamo lahko pri trditvi, da je Vergerij kljub svojemu spreobrnjenju ostal humanistični univerzalist (Marinčič 2018, 22) in vrhunski intelektualec, kar je bil že prej, sicer ne bi pristal v Contarinijevi komisiji. Ostajal je zvest latinskemu jeziku kot jeziku humanističnih intelektualcev, v katerem je sestavil vrsto propagandističnih (Pierce 2003) in polemičnih spisov (ne pa tudi sodnih: Otto difesioni so v italijanskem jeziku). S spisom Concilium non modo Tridentinum sed omne papisticum perpetuo fugiendum omnibus piis (»Vsi pobožni ljudje bi se morali izogibati ne le Tridentinskemu, pač pa vsem papeškim koncilom «) je sprožil serijo polemik proti koncilom, ki jo je leta 1556 nadaljeval z delom »Dopisi papeškega tajnika" (Duae actiones secretarii pontificii), podnaslovljeni »Naj papež Pavel IV. razmisli o ponovnem sklicu Tridentinskega koncila?« (An Paulus Papa IIII debeat cogitare de instaurando Concillio Tridentino) in "Ali sme papež z orožjem vsiliti protestantom sklepe koncila?" (An [Papa] vi et armis possit deinde imperare Protestantibus ipsius Concilii decreta). Zlasti druga od obeh razprav (pravzaprav invektiv proti papežu Pavlu IV.) razodeva Vergerijev humanistični univerzalizem, ki je pokopal tudi njegove upe na udeležbo na koncilu (Cavazza 2013, 12). Mimo vprašanj o literarni predlogi (prim. Pobežin 2018a) se tu vrnemo k tradiciji Divovih prologov in trditvi o "pre-branju« Salustijevih moralnih prologov. Tu se nam Vergerij kaže kot tragična žrtev razmer, v katere so ga potisnili tudi njegovi humanistični univerzalni nazori (v tem sploh ni bil osamljen - prim. Jovanović 2018): zmožnost pogledati onkraj lastnega stališča, kakršno je izkazal v Contarinijevi komisiji in zaradi katere je zagovarjal trditev, da ni smiselno v nedogled vztrajati pri vnaprej določeni lokaciji koncila, je podžgala sume o njegovem odpadništvu. $\mathrm{V}$ svetu, kjer so se krepili radikalnejši pogledi Contarinijevih nasprotnikov, je bil položaj med jastrebi Caraffovega kova varnejši.

Zato je primerjava njegovih stališč s salustijansko dilemo na mestu: rimska historiografska obdelava poznega republikanskega obdobja je vabila k utrjevanju humanistične ideje o dveh diametralno nasprotnih silah, med kateri je bila razpeta človekova eksistenca v okviru (poljubne) držav- 
ne strukture, namreč libertas in imperium (Hörnkvist 2003, 110), k čemur napeljujejo antični literarni zgledi; diskurz, osredotočen na vrednote v njihovi dihotomni jukstapoziciji, je tu osrednjega pomena za pripoved prevrata (stasis narrative). Če je tu Vergerij Salustijev učenec (tudi če je trditev pretirana), je Salustij Tukididov učenec. Ko namreč Tukidid govori o prevratu v Korkiri, pove naslednje $(3,82,4-5)$ :

Poljubno so spreminjali celo običajni pomen besed, ki velja navadno za oceno dejanj. Nerazsodno drznost so ocenjevali kot zvesto in prijateljsko hrabrost, $v$ trezno premišljeni razsodnosti so videli olepševanje boječnosti in pametna umerjenost je veljala za pretvezo nemožatosti. (Tukidid 1958, 185)

Vergerij se je v loku usode znašel na podobno neudobni ostrini. Zlasti v svoji drugi razpravi »Dopisov papeškega tajnika« je vzpostavil natanko to opozicijo, namreč libertas - imperium, v čemer se je povsem približal Salustiju. V prvi razpravi namreč v okviru legalistične razprave o spornih členih koncilske razprave močno izpostavi vprašanje sloge (concordia), ki je njegovem mnenju (to seveda ugotavlja ex post) ni možna. Literarne predloge iz pozne rimske republike (sentiment je zlasti izražen pri Salustiju) so tu narekovale vsako pomanjkanje optimizma: pot je vodila le še proti postopnemu hiranju republike (Kapust 2011, 47), ki so ga v Salustijevem času pospeševale zarote in posamezniki, ki jih ni več ustavil noben republikanski zakon. To je bila pot v prepad, ki je narekovala vprašanje, katere vrednote so k temu pripeljale. Odgovor je v svojih prologih ponujal Salustij.

Vergerij se je tu znašel na neudobni ostrini med antitetičnimi pari vrednot (na nedavni konferenci smo jo imenovali kar »Vergerijeva britev« - Pobežin 2019), ki jih je v omenjenih spisih jasno razporedil vzdolž humanističnega branja antičnih besedil, v katerih je pripoved o prevratu $\mathrm{v}$ veliki meri odvisna prav od razumevanja kardinalnih vrednot, s čimer ni imel težav. Imel pa je jih je prav zaradi tiste svoje kakovosti, ki ga je ogrozila že v Contarinijevi komisiji, in sicer univerzalne humanistične zmožnosti »pogleda onkraj« (pismo Oporinu - gl. Štoka 2018).

\section{Namesto zaključka}

Leta 1537 se je Vergerij vrnil v Koper »ovenčan s škofovsko častjo « kakor $p a$ ter patriae, ki ga v panegiričnem pismu - prologu slavi prvi pesnik Kopra oziroma Justinopolisa, »koprski Homer«. Ne glede na to, kdaj se je svojemu poklicu posvetil $\mathrm{z}$ resnično prenoviteljsko vnemo, njegova biografija uči, 
da ga je prav iz vrst lastne škofije zadela obtožba herezije, ki se je končala $\mathrm{z}$ njegovim begom iz Italije leta 1549 . V prvi polovici leta 1548 se je morda še zdelo, da bodo obtožbe končno opuščene, a je bil postopek še istega leta obnovljen in Vergerij je odšel v izgnanstvo, kjer je leta 1565 tudi umrl. A zgodba se tu ne konča. Če je Koper, kakor smo dejali uvodoma, leta 1537 z izdajo Divovega prevoda Iliade in Odiseje na neki način postal središče sveta, je leta 1572, sedem let po Vergerijevi smrti, vsaj za hip postal »drugi Rim«. Sum odpadništva, zaradi katerega je iz Kopra zbežal Peter Pavel Vergerij, je padel tudi na njegovega starejšega brata Giovannija Battista (roj. ok. 1492), ki je umrl sredi leta 1548. Koper je leta 1572 postal prizorišče posebne mrtvaške sinode (synodus horrenda): kosti Giovannija Battista, pokopanega $\mathrm{v}$ poslopju stolnice, naj bi izkopali in vrgli v morje (Stankovich $1828,294)$. S to letnico je bržkone mogoče obeležiti tudi po vsej verjetnosti sočasen dogodek, in sicer "preklic spomina (damnatio memoriae) na napisu, ki se je do nedavnega nahajal vzidan desno od vhoda v stolnico. Napis je bil posvečen najstarejšemu od treh bratov, Aureliu Vergeriju, na njem pa sta bili izpričani tudi imeni mlajših bratov, ki sta omenjena kot naročnika napisa leta 1548 (o tem podrobneje Pobežin 2020). Sklepno dejanje Vergerijeve usode v Kopru torej zaključuje njegov lok kot popolna razveljavitev panegirika iz leta 1537: z izbrisom imena. Toda do tistega časa je krožilo že nekaj ponatisov Divovih latinskih Iliade in Odiseje.

\section{Literatura}

Benedetto, G. 2005. »Le versioni Latine dell'Iliade.« V Vincenzo Monti nella cultura Italiana, ur. G. Barbarisi, 961-1027. Milano: Cisalpino.

Cavazza, S. 2013. "Nenavadna osebnost: profil Petra Pavla Vergerija.« Stati inu obstati: revija za vprašanja protestantizma 17-18: 10-26.

Gantar, K. 1970. »Andreas Divus iz Kopra - prevajalec Homerja.« Zgodovinski časopis $24(3-4): 273-78$.

Hörnkvist, M. 2003. "The Two Myths of Civic Humanism.« V Renaissance Civic Humanism: Reappraisals and Reflections, ur. J. Hankins, 105-42. Cambridge: Cambridge University Press.

Jambrek, S. 1999. "Petar Pavao Vergerije ml. i Rasgovarange megiu papistu $i$ gednim luteran."Acta Histriae 7 (8): 141-52.

Jovanović, N. 2018. »Pavao Skalić protiv Pier Paola Vergeria«. V Actiones duae secretarii pontificii Petri Pauli Vergerii, ur. G. Pobežin in P. Štoka, 27-57. Koper: Osrednja knjižnica Srečka Vilharja. 
Kapust, D. J. 2011. Republicanism, Rhetoric and Roman Political Thought: Sallust, Livy and Tacitus. Cambridge: Cambridge University Press.

Marinčič, M. 2016. »Lie Quiet, Divus: homerska prerojenja in rojstvo modernizma iz duha latinske poezije."V Divina - Andreas Divus Iustinopolitanus, ur. G. Pobežin in P. Štoka, 31-51. Koper: Osrednja knjižnica Srečka Vilharja.

Marinčič, M. 2018. »Amore patriae teneri non potuit: dva Vergerija o Hieronimu (in o mejah lokalnega patriotizma).«V Actiones duae secretarii pontificii Petri Pauli Vergerii, ur. G. Pobežin in P. Štoka, 11-25. Koper: Osrednja knjižnica Srečka Vilharja.

McDonnell, M. 2006. Roman Manliness: »Virtus« and the Roman Republic. Cambridge: Cambridge University Press.

Osmond, P. J. 1995. »Princeps Historiae Romanae: Sallust in Renaissance Political Thought «. Memoirs of the American Academy in Rome 40: 101-13.

Pierce, R. A. 2003. Pier Paolo Vergerio the Propagandist. Rim: Edizioni di storia e letteratura.

Pobežin, G. 2016. "Andreas Divus - uganka na pragu moderne dobe.« V Divina - Andreas Divus Iustinopolitanus, ur. G. Pobežin in P. Štoka, 8399. Koper: Osrednja knjižnica Srečka Vilharja.

Pobežin, G. 2018a. »Magna enim est spes de pace - Vergerijev spis Duae actiones secretarii pontificii in njegova stališča do Tridentinskega koncila.« V Actiones duae secretarii pontificii Petri Pauli Vergerii, ur. G. Pobežin in P. Štoka, 59-89. Koper: Osrednja knjižnica Srečka Vilharja.

Pobežin, G. 2018b. "Nihil odiosius quam nomen Italorum: Vergerij mlajši med humanističnim univerzalizmom in nacionalizmom.« Primerjalna književnost 41 (2): 99-116.

Pobežin, G. 2019. »Vergerijeva britev - o srednjeveških in humanističnih branjih antičnih besedil.« V Razvoj kolektivnih (etničnih) identitet na Slovenskem skozi prizmo zgodovine dolgega trajanja (povzetki referatov), ur. V. Kočevar in B. Golec, 37. Ljubljana: Založba ZRC.

Pobežin, G. 2020 »Napis Vergerijev v koprski stolnici - kratka zabeležka in rekonstrukcija napisnega polja.« Studia universitatis hereditati 8 (1): 97-102.

Schutte, A. J. 1977. Pier Paolo Vergerio: The Making of an Italian Reformer. Ženeva: Librairie Droz.

Stankovich, P. 1828. Biografia degli uomini distinti d'Istria. Trst: Marenigh.

Štoka, P. 2018. "Magna enim est spes de pace - Vergerijev spis Duae actiones secretarii pontificii in njegova stališča do Tridentinskega koncila.« V 
Actiones duae secretarii pontificii Petri Pauli Vergerii, ur. G. Pobežin in P. Štoka, 59-89. Koper: Osrednja knjižnica Srečka Vilharja.

Teza, E. 1903. »Quale fosse il casato di Andreas Divus da Capodistria vecchio traduttore di Aristofane? « Rivista di storia antica 7: 85-98.

Tukidid. 1958. Peloponeška vojna. Ljubljana: DZS.

Vergerij, P. P. 2018. Dopisi papeškega tajnika - Actiones duae secretarii pontificii. Ljubljana: Založba ZRC.

\section{Summary}

The Highly Unusual Century: Humanism in $16^{\text {th }}$ Century Istria between panegyric and damnatio memoriae

The paper explores common points between the prologues of the Justinopolitan bard Andreas Divus, the translator of Homer's Iliad and Odyssey, and the prologues of Sallust's historical monographs. Dedicated to Pier Paolo Vergerio the Younger (1498-1565) and his secretary Otonello Vida, the prologues mimic in their design Sallust's moral and philosophical reasoning from his Catilinarian Conspiracy and Jugurthine War, in which iconic antitheses were brought forward. The dichotomy of spirit vs. body, silence vs. memory, silence vs. glory and the redefined cardinal virtues have served scores of authors as a matrix against which contemporary phenomena such as state, power of rulers, and more abstract concepts of liberty, unity etc. were measured. These texts were read and re-read repeatedly according to ever-present political needs, in the Middle Ages and the Renaissance period, north and south. Seemingly frivolous in their use of Sallustian topoi, Divus' prologues are, in fact, more than just allusions to Vergerio's otium: they serve as an allegory of the dilemmas that Vergerio had already overcome - but also the dilemmas he was yet about to face. 